\title{
Enabling Productive But Asset-Poor Farmers to Succeed: A Risk Financing Framework
}

\author{
Eugene Gurenko and Olivier Mahul \\ Insurance and Contractual Savings Practice \\ Financial Sector Operations and Policy Department
}

\begin{abstract}
:
Gurenko and Mahul examine how market-based risk financing instruments could enable asset-poor but productive farmers exposed to production shocks to engage in riskier but higher return agricultural activities. The financing of these exogenous shocks is addressed in a conceptual framework based on an optimal allocation of capital where the farm is viewed as a business unit. The approach allows for (i) testing the business viability of a specified crop by assessing the minimum business capital required to ensure the continuity of the business after the occurrence of an adverse production shock; and (ii) designing an optimal risk financing program to finance the minimum capital requirements using a combination of instruments (insurance, savings, and borrowing). The authors provide numerous numerical and graphical examples to illustrate the relevance of this financial approach to the specific issues of agricultural risk management.
\end{abstract}

Key words: agricultural business unit, capital allocation, cost of risk, credit, insurance, price discovery, profitability, savings, viability.

Acknowledgements: We would like to thank Jerry Caprio, Patrick Honohan and Luc Laeven for their helpful comments and suggestions which improved the analytical quality of the paper. Remaining errors or omissions are ours.

World Bank Policy Research Working Paper 3211, February 2004

The Policy Research Working Paper Series disseminates the findings of work in progress to encourage the exchange of ideas about development issues. An objective of the series is to get the findings out quickly, even if the presentations are less than fully polished. The papers carry the names of the authors and should be cited accordingly. The findings, interpretations, and conclusions expressed in this paper are entirely those of the authors. They do not necessarily represent the view of the World Bank, its Executive Directors, or the countries they represent. Policy Research Working Papers are available online at http:/lecon.worldbank.org. 


\section{Introduction}

Agricultural risk management is an inherent part of the development and poverty agenda because it can contribute significantly to poverty reduction. In most countries, and particularly in developing countries, farmers' income is highly vulnerable to numerous risks, especially the production risk commonly associated with weather related events. Such events cause significant income fluctuations, can be a major threat to farmers' financial survival, and can be difficult to manage. The inherent instability of farm income has led governments to devise numerous agricultural income stabilization programs and policies, with crop insurance being among the most prevalent. A survey conducted by the Food and Agriculture Organization (FAO) in the early 1990s reveals that various types of crop insurance programs are present in more than 140 countries (FAO 1991). Most of them, if not all, rely heavily on government subsidies.

However, despite the prevalence of government subsidies, the overall financial experience of traditional crop insurance has been disappointing and, in many instances, disastrous. Low insurance penetration despite high premium subsidies, mostly captured by large farmers, consistent underestimation of the systemic component of production risk, poor financial performance with claims consistently exceeding premiums, inappropriate pricing methodologies, uncontrolled moral hazard, and adverse selection are a few of the key endemic problems that plague national agricultural insurance programs worldwide (Hazell, Pomarelda and Valdes 1986; FAO 1991; Anderson 2001) ${ }^{1}$.

Previous government efforts to develop viable national crop insurance programs have also been frustrated by the inherent lack of clarity regarding the objectives that, depending on policymakers' view, range from providing social safety nets to risk management. As a risk management instrument, crop insurance, in addition to other financial instruments (savings and credit) and preventive activities, can play a vital role in enabling farmers to deal with production risk and help them to restore their business viability after crop failures. As a social instrument, crop insurance can protect poor farmers from the economic consequences of adverse production shocks, thus restoring their livelihoods.

In the early 1980s, the realization of these daunting challenges led the World Bank to withdraw from providing technical and financial support to government sponsored agricultural insurance programs. However, since the late 1990s, due to the dwindling government subsidies to agricultural producers in developing countries, there has been a renewed interest among development lenders in using agricultural insurance as an important risk management tool that can enhance the business viability of agriculture in developing countries. The emergence of a new generation of parametric and index-based insurance products, which to a large extent, manage to address the moral hazard problem, was another contributing factor that led to revisiting the potential role of agricultural insurance in these economies. The World Bank has initiated a series of feasibility studies on weather-based index insurance in several countries (including Morocco, Nicaragua, and Tunisia) but, until now, none of these innovative programs has been implemented on a larger scale due to the lack of a coherent integrated and practical agricultural risk management framework that could ground these types of instruments in the concept of crops' market viability - the main topic of this work.

\footnotetext{
${ }^{1}$ Hazell, Pomarelda and Valdes (1986) provide a comprehensive analysis of crop yield risk management in developing countries. They investigate the role of public agricultural risk management policies in general and crop insurance in particular in dealing with the variability of farm income.
} 
This paper is the second output of the study "The Financing of Agricultural Production Shocks: A Market-Based Approach". ${ }^{2}$ The purpose of this paper is to develop a conceptual framework for financing agricultural production shocks with market-based instruments. Hence, it focuses on the risk of adverse agricultural production shocks causing drops in crop yields and on how formal market-based instruments (such as insurance/hedging, and savings/borrowings) can enable farmers to manage it.

Relying on the latest advancements in crop yield risk modeling, actuarial science, insurance and financial economics, the paper attempts to develop clear guidelines for examining the financial (business) viability of a specific crop, once the hedging costs are considered. The proposed optimal risk financing structure developed under this approach is based on an actuarial analysis of production risk characteristics and the consequent risk decomposition into distinct layers. Based on the frequency and severity characteristics of each risk layer and the farmer's financial profile, an optimal combination of risk financing techniques consisting of insurance, savings and credit is proposed. In deriving an optimal financial structure, we consider the cost of these risk management instruments which enables us to draw some interesting conclusions about the pricing of risk hedging instruments, the concept of insurability, and ultimately the business viability of the examined crops.

One of the principal messages conveyed by this paper is that market-based solutions, without public subsidies, can enable asset-poor farmers involved in profitable business activities to maintain the viability of their agricultural business in the long run despite their constant exposure to weather-related exogenous production shocks, which sometimes can be catastrophic. This paper proposes a new typology of crop business activities based on (i) the profitability of the crop business and (ii) farmers' ability to absorb exogenous production shocks. This typology identifies crop business activities that could benefit from market-based risk financing solutions and those that cannot be sustained without government subsidies. It thus provides a new rationale for the role of government and the private markets in the management of agricultural production risks.

The paper is structured to highlight the main ideas and initiate debate to further the discussion. Section 2 summarizes the multiple risks faced by farmers and the respective multiple risk management strategies. Section 3 presents a detailed analysis of production risk, the only risk examined in this paper, and discusses the concepts of crop business viability and profitability in light of farmers' ability to absorb adverse weather related production shocks. It also identifies the type of farmers that would benefit most from external market-based sources of risk financing. Section 4 investigates how insurance and self-insurance, including savings and debt, could be efficiently combined to provide cost-effective risk management solutions custom-tailored to the specific needs of crop farmers. Section 5 presents a brief summary of the key findings and contributions of the paper.

\section{Multiple Risks and Multiple Risk Management Arrangements}

There has been a growing body of work at the World Bank on the relationship between poverty and risk and efforts to manage risk. In a series of discussion papers on social protection, Siegel and Alwang (1999), Siegel (2000), Holzmann and Jorgensen (2000), and Heitzmann, Canagarajah and Siegel (2002) examine how to identify and manage risks in rural

\footnotetext{
${ }^{2}$ The first output is a technical paper on combining insurance, contingent debt and insurance in an optimal corporate risk financing strategy (Gurenko and Mahul 2003).
} 
areas. In the agricultural context, Anderson (2001) reviews risk management instruments and discusses market failures and rationale for government intervention.

Farmers in developing countries are vulnerable to multiple exogenous risks that may vary from those affecting a single person (idiosyncratic risk) to those that can devastate whole communities (systemic risk). As can be seen from Table 1, some of these risks are common for all households, while others are specific to agricultural production, which is inherently risky due to unforeseen systemic risk exposures to weather (production risk) and the pricing volatility of commodity markets (price risk). In addition, the sources of risk and their impact on the income of rural households can vary by farm size and farm type.

Table 1. Main sources of agricultural risks

\begin{tabular}{|c|c|c|c|}
\hline & $\begin{array}{c}\text { Micro } \\
\text { Idiosyncratic }\end{array}$ & & $\begin{array}{c}\text { Macro } \\
\text { Systemic }\end{array}$ \\
\hline \multicolumn{4}{|l|}{ Production } \\
\hline Natural & & Hail & $\begin{array}{c}\text { Earthquake, floods, } \\
\text { drought }\end{array}$ \\
\hline Diseases and pests & & Pest infestation & $\begin{array}{c}\text { Animal contagious } \\
\text { disease }\end{array}$ \\
\hline Price & & & $\begin{array}{c}\text { Commodity, inputs, } \\
\text { exchange rates }\end{array}$ \\
\hline Financial & & & Interest rate, \\
\hline Environmental & & Pollution, deforestation & \\
\hline Institutional & & & $\begin{array}{l}\text { Public subsidies, } \\
\text { Agricultural policy }\end{array}$ \\
\hline Health & Illness, injury, disability & Epidemic & \\
\hline Property & Fire, theft & & Earthquake, floods \\
\hline
\end{tabular}

Sources: Authors, adapted from Holzmann and Jorgensen (2000).

Farmers can use several strategies, whenever they are available, to deal with these multiple sources of risk. It is common to differentiate these strategies into two main categories: risk management and risk coping. While risk management strategies attempt to address the risk ex ante, risk coping strategies are addressing it ex post. One can also differentiate between technical and financial risk management approaches. For instance, an example of a technical risk management arrangement would be the selection of less risky agricultural production techniques, the use of preventive activities, or diversification of income sources. Financial protection can be obtained from insurance companies and capital markets. Examples of these risk management arrangements are presented in Table 2. 
Table 2. Examples of risk management arrangements

\begin{tabular}{|c|c|c|}
\hline $\begin{array}{c}\text { Arrangement } \\
\text { Strategies }\end{array}$ & Technical & Financial \\
\hline Risk Management & $\begin{array}{l}\text { - Low-risk productive pathways } \\
\text { - Pest prevention (pesticides, } \\
\text { herbicides...) } \\
\text { - Livestock disease prevention } \\
\text { (vaccination...) } \\
\text { - On-farm diversification (crop } \\
\text { rotation, livestock and crops...) } \\
\text { - Off-farm diversification }\end{array}$ & $\begin{array}{l}\text { - Insurance } \\
\text { - Hedging } \\
\text { - Savings } \\
\text { - Contingent borrowing }\end{array}$ \\
\hline
\end{tabular}

Sources: Authors, based on Holzmann and Jorgensen (2000) and Anderson (2001).

Given the multiple risks affecting farmers' income and consumption and the multiple risk management and risk coping arrangements that exist, it would be unrealistic to treat all these heterogeneous risks and risk financing instruments in a single framework. As a consequence, the approach adopted in this study first decomposes the risk by separating price and crop yield risks with a view to focusing on the latter. We then examine formal marketbased instruments (insurance/hedging and savings/credit) that can be effective in managing this agricultural production risk ${ }^{34}$ Thus, this paper should be viewed as a first module to be combined with other modules dealing with other sources of risk faced by farmers in a comprehensive analytical approach to the variability of income in agriculture.

\section{Crop Business Viability}

In this market-based framework, farming is viewed as a business activity exposed to multiple production risks. These sources of uncertainty in the short-run can affect the crop business profitability, and in the long run the business viability, in the worst cases, leading to insolvency.

A three-step approach is proposed to analyze the viability of crop business, as depicted on Figure 1. First, the yield risk characteristics of the specified crop are analyzed, where the catastrophic and non-catastrophic components of the risk are separated. The crop business profitability is assessed based on the comparison between the crop yield pattern and the production costs. The minimum business capital requirements allowing the farmer to stay in business are then derived. Second, we examine the farmer's financial profile, and especially his asset base, which determines his ability to utilize internal resources to meet his business capital requirements prescribed by the necessity to absorb the economic consequences of adverse production shocks. Third, the viability of the crop business is tested by comparing the minimum capital requirements with the farmer's asset base. The comparison also allows to determine whether additional external sources of capital (insurance, savings/borrowings) are needed to enhance or restore the farmer's risk retention capabilities. Hence, this market-based approach (i) enables to establish whether the farmer's asset base is sufficient to meet the

\footnotetext{
${ }^{3}$ This paper does not discuss the design of cost-effective insurance/hedging contracts. Consequently, insurance and hedging are broadly viewed as synonymous, i.e., as risk transfer instruments between two parties.

${ }^{4}$ Although, under certain circumstances (such as market failures), formal credit and insurance markets may be ineffective in reducing income risk and its consequences (Dercon 2002), the market based approach developed in this paper will allow us to build a framework in which complex issues of insurance economics can be examined using mathematical tools and, to some extent, simulation models.
} 
minimum capital requirements and (ii) identify asset poor but productive farmers who could benefit most from market-based sources of risk financing.

\section{Figure 1. Crop business viability}

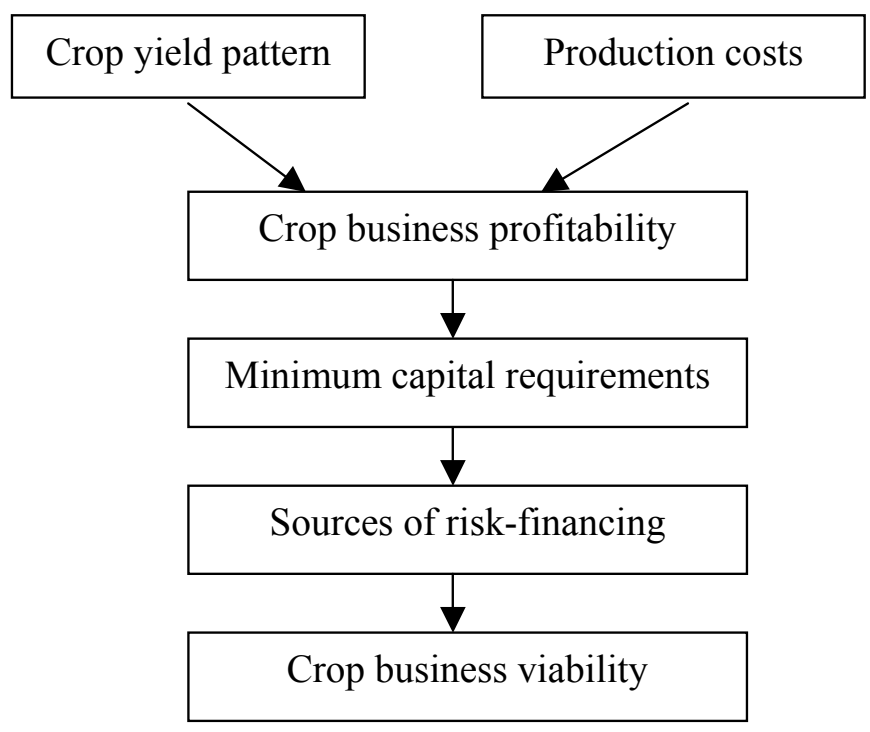

Source: Authors.

\subsection{Crop Yield Risk Characteristics}

Similar to many other non-agricultural business activities, crop farming is subject to many risks. The difference, however, lies in its considerable exposure to natural disasters (drought, floods...) frequently affecting agriculture which cannot be prevented due to potentially prohibitive costs of preventive actions. Large losses stemming from catastrophic events can greatly affect the profitability of agriculture and, in the worst cases, can lead to insolvency of crop farmers. ${ }^{5}$ Hence, catastrophic events and their economic consequences are seen frequently as economic rationale for public support through subsidized insurance premiums or subsidized interest rates (Miranda and Glauber 1997). However, in a marketbased context, private risk markets could finance both catastrophic and non-catastrophic risks as long as the profitability of crop businesses is high enough to allow farmers to purchase market risk-financing instruments and, at the same time, cover their main production costs without public subsidies.

As shown in Figure 1, the business profitability of the crop depends on its yield risk characteristics and the production costs. In our framework, the production costs are defined as a fraction $\alpha$ of the average crop yield, and they are assumed to be non-random. The average operating profit margin is thus equal to $(1-\alpha)$ times the average crop yield. Operating losses are defined as the difference between the production costs and the actual crop yield, when

\footnotetext{
${ }^{5}$ The profitability of the specified crop is measured by the operating profit margin. It reflects the ability to generate revenues and control costs in such a way as to generate an operating profit. It is positive when the actual crop yield is higher than the associated cost. In our model, the operating profit variability is only caused by the crop yield uncertainty.
} 
positive. ${ }^{6}$ Under this approach, the crop business profitability is determined by the downside risk characteristics of the specified crop. If the crop yield is lower than the production costs, the survivability of the crop business activity will depend on the farmer's ability to absorb this income shock. The viability of the crop business thus relies on the farmer's financial reserves or external capital to cover the unexpected operating losses, which is the minimum amount of capital required to ensure the continuity of the business after the occurrence of an adverse production shock. The relationship between the crop yield risk characteristics and the minimum capital requirements is illustrated in Box 1.

\section{Box 1. Crop yield losses and minimum capital requirements}

Data on cocoa and banana yields from 1961 to 2002 in a South American country are used for the sake of illustration. Data are first detrended using a polynomial procedure. First order serial correlation is tested and the hypothesis of serial correlation is rejected. The figure below shows the variability of these two crops expressed in percentage of the average (adjusted) crop yields, which are estimated at $168.89 \mathrm{~kg} / \mathrm{ha}$ for cocoa and 23.42 $\mathrm{mt} / \mathrm{ha}$ for banana. Cocoa yields are more variable than banana yields and exposed to higher extremes.

\section{Variability of banana and cocoa, in percentage of average yields.}

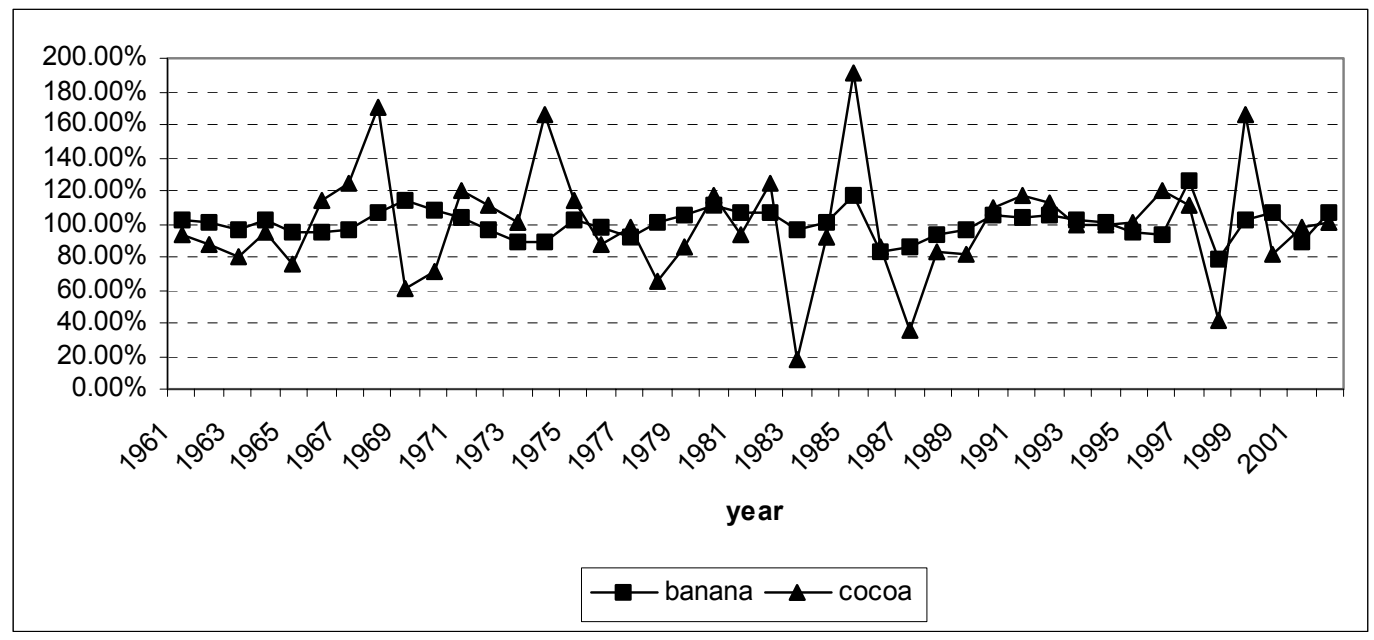

The cumulative distribution functions (CDF) of the operating losses are simulated for different levels of average operating profit margin. The downside risk is measured by the Value at risk (VaR) which summarizes the worst loss over a target horizon with a given level of confidence. Formally, this is a specified quantile of the CDF of the operating losses. For example, $\operatorname{VaR}(5 \%)$ is the worst operating loss in a $95 \%$ confidence interval. It determines the minimum capital required to absorb potential losses and thus ensures the viability of the crop business following the occurrence of a loss. The higher the average operating profit margin is, the lower are the potential losses and thus the minimum business capital requirements.

The table below presents the minimum capital requirements for two different crops depending on the farmer's average operating profit margin. It shows that the reserves required for cocoa production are much larger that those required for banana production, as a consequence of the greater (downside) variability of the cocoa yields. When the average operating profit margin is $5 \%$, the amount of capital needed to absorb unexpected production shocks with a $95 \%$ confidence interval is equal to $58.2 \%$ of the average yield for cocoa and $19.7 \%$ for bananas. When the average operating profit margin is $20 \%$, the amount of capital is $46.2 \%$ and $2.9 \%$ for cocoa production and banana production, respectively.

\footnotetext{
${ }^{6}$ Formally, operating loss $=\max [(1-\alpha) \bar{y}-y, 0]$, where $\bar{y}$ is the average crop yield, $y$ is the actual yield and $\alpha$ is the average operating profit margin. Operating loss is thus equal to negative operating profit margin.
} 
Minimum capital requirements (in \% of average yields)

\begin{tabular}{lccccc}
\hline & \multicolumn{5}{c}{ Average operating profit margin (in \% of average yields) } \\
& $5 \%$ & $10 \%$ & $15 \%$ & $20 \%$ & $25 \%$ \\
\cline { 2 - 6 } Cocoa & $58.2 \%$ & $54.7 \%$ & $49.4 \%$ & $46.2 \%$ & $41.4 \%$ \\
Banana & $19.7 \%$ & $13.1 \%$ & $4.3 \%$ & $2.9 \%$ & $1.4 \%$ \\
\hline
\end{tabular}

Source: Authors.

The amount of capital required to ensure the viability of the business in the long run may be high and it increases with the exposure of the crop yield to extreme events. The concept of catastrophic risk adjusted (CRA) crop yield is introduced to examine the impact of catastrophic events on the crop business profitability. It is defined as a crop yield adjusted for catastrophic events where, following an actuarial approach, catastrophes are defined as infrequent events, e.g., occurring once in twenty years or more. Therefore, the downside risk caused by catastrophic events is removed with an hypothetical put option priced at its fair value. The minimum capital requirements are estimated from the operating losses adjusted for the catastrophic risk. Obviously, they are lower than those non-adjusted for catastrophic risk because the catastrophic events have been removed. The value added created by the catastrophic coverage increases with the degree of exposure of the crop to extreme events. This is illustrated in Box 2.

\section{Box 2. Catastrophic risk adjusted crop yields and minimum capital requirements}

Detrended data on cocoa yields and banana yields from 1961 to 2002 in a South American country are used for the purposes of illustration. A catastrophic event is defined here as an event occurring on average once in 20 years or less frequently. Given the simulated cumulative distribution function of the crop yields, this catastrophic event occurs when the national cocoa yield falls below $70 \mathrm{~kg} / \mathrm{ha}$ (strike). This event has occurred twice since 1961 (1983 and 1987). The actuarially fair price of this hypothetical coverage (i.e., put option with a strike at 70 $\mathrm{kg} / \mathrm{ha}$ ) is estimated at $0.72 \%$ of the average yield.

Crop yields and catastrophic risk adjusted crop yields (one in 20 year event), national cocoa yield

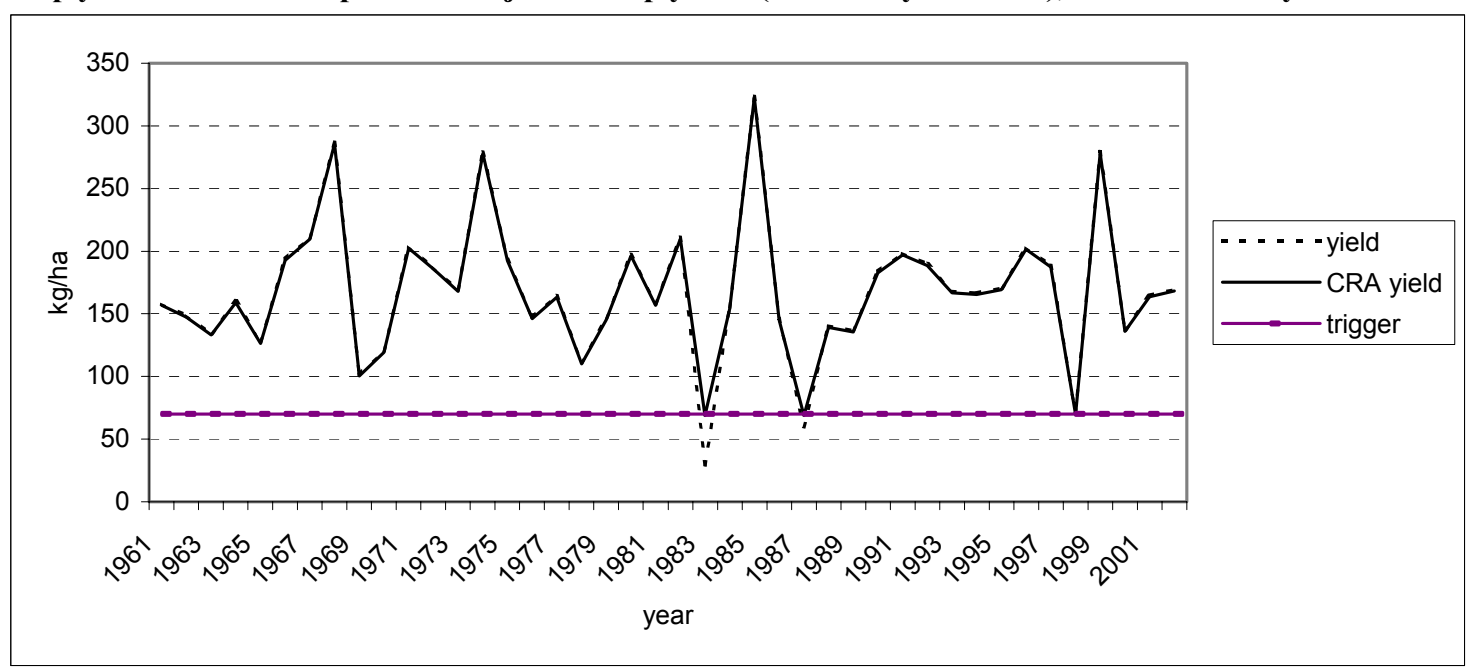


Regarding banana production, the strike is equal to $22.1 \mathrm{mt} / \mathrm{ha}$ and the actuarial fair price of this hypothetical coverage is estimated at $0.29 \%$ of the average yield.

Formally, the CRA crop yield is defined as

$$
y^{C R A}=\min (\hat{y}, y)-P .
$$

where $y$ is the actual yield, $\hat{y}$ is the strike and $P=E \max (\hat{y}-\tilde{y}, 0)$ is the actuarially fair catastrophe insurance premium.

The minimum business capital requirements adjusted for the catastrophic risk are presented below. The impact of the catastrophic risk on the amount of capital is significant, especially for the cocoa production which is more variable than the banana production. For instance, when the operating profit margin is $5 \%$, the catastrophe coverage reduces the minimum capital requirements by $11.0 \%$ for cocoa and $3.4 \%$ for bananas. The value added created by the catastrophe coverage is higher for cocoa than for bananas because the former is more exposed to extreme weather events.

Minimum capital requirements (in \% of average yields) for CRA crop yields

\begin{tabular}{lccccc}
\hline & \multicolumn{5}{c}{ Average operating profit margin (in \% of average yields) } \\
& $5 \%$ & $10 \%$ & $15 \%$ & $20 \%$ & $25 \%$ \\
\cline { 2 - 6 } Cocoa & $47.2 \%$ & $45.5 \%$ & $43.4 \%$ & $35.7 \%$ & $30.8 \%$ \\
Banana & $(-11.0 \%)^{\mathrm{a}}$ & $(-9.2 \%)$ & $(-6.0 \%)$ & $(-10.5 \%)$ & $(-10.6 \%)$ \\
& $16.6 \%$ & $11.4 \%$ & $3.6 \%$ & $2.3 \%$ & $1.2 \%$ \\
& $(-3.1 \%)$ & $(-1.7 \%)$ & $(-0.7)$ & $(-0.6 \%)$ & $(-0.2 \%)$ \\
\hline
\end{tabular}

${ }^{a}$ Numbers in parentheses are the difference between the minimum capital requirements for CRA crop yields and those for (non-CRA) crop yields which are presented in Box 1.

Source: Authors.

\subsection{Farmer's Financial Profile}

The farmer's ability to absorb exogenous production shocks causing operating losses depends on his ability to raise sufficient resources to meet the costs until the next harvest season. These capital requirements can be met with either internal or external capital.

Liquidity can be obtained from utilizing the farmer's internal capital resources, such as cash reserves (precautionary savings) or through the sale of less liquid assets (livestockor jewelry). Thus, it is his financial profile, and especially the structure of the farmer's asset base, that determines his ability to absorb exogenous production shocks and maintain the business following crop yield shortfalls.

Market-based risk financing instruments can provide access to external sources of capital after the occurrence of a loss through insurance or contingent debt. In cases when the cost of this external capital is lower than the cost of the internal capital, access to this additional risk-absorbing capacity may enhance the viability of the farmer's business or, in some cases, restore it. However, this additional risk financing capacity from external capital providers is costly, which limits its use to productive farmers involved in crop business activities generating a sufficiently high profit margin.

The role of external risk financing solutions as business enhancing instruments is illustrated in Figure 2. The efficient frontier for a farmer with no access to external risk financing tools is drawn for the expected return vs. return variability levels. Technology A generates low (expected) return, but it also exposes farmers to low production risks. On the contrary, technology B has a higher expected return but is riskier. Asset-poor but productive 
farmers are forced to adopt a low-return and low-risk technology because their limited financial capacity would not allow them to absorb larger exogenous production shocks. They are thus confined in the vicious circle of poverty. External risk financing instruments, like insurance or contingent debt, can help these farmers to adopt higher return but riskier technologies as long as they generate enough operating profit to cover the hedging costs. This is illustrated on Figure 2a, where access to these risk financing instruments allows farmers to move from point $\mathrm{A}$ to point $\mathrm{C}$, via point $\mathrm{B}$. The move from $\mathrm{A}$ to $\mathrm{B}$ can result, for instance, from an increase in the use of risk-increasing inputs such as fertilizers. ${ }^{7}$ In this example, the farmer transfers the additional risk due to the adoption of technology B to an external investor such as an insurance company, for instance, which in turn enables him to reach point C. A fraction of the additional expected profit realized from this move is used to pay for the hedging costs. The difference between the additional expected return and the hedging costs involved is the value added of the external financing arrangements.

However, if hedging costs are greater than the additional expected return generated by the adoption of a high-return and high-risk technology, then market-based instruments are not economical and thus are not purchased by farmers, as depicted in Figure $2 \mathrm{~b}$. The optimal risk financing solutions are illustrated in Box 3.

\section{Figure 2a. Risk financing instruments as crop business profitability enhancing} solutions

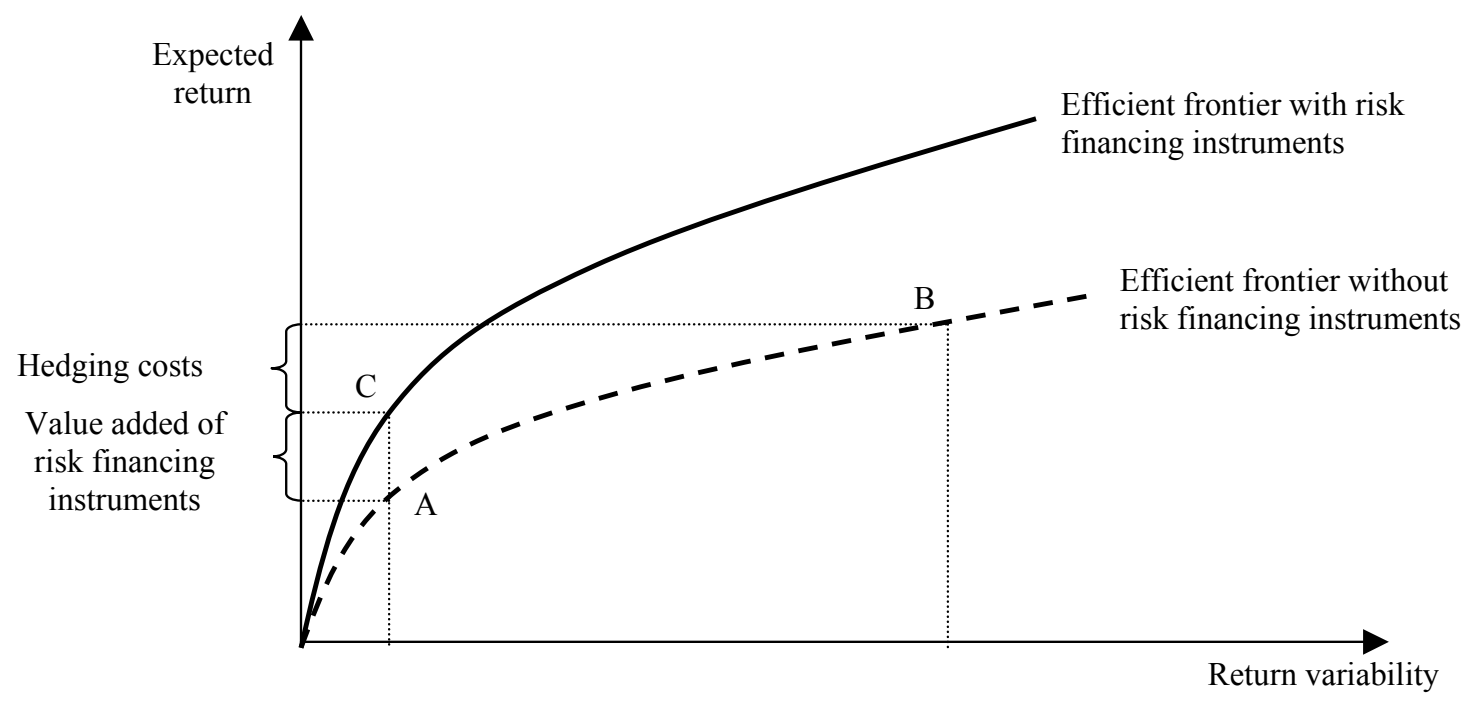

Source: Authors.

\footnotetext{
${ }^{7}$ The marginal productivity of risk-increasing inputs increases (resp. decreases) as the states of nature (i.e., the level of rainfall) are more (resp. less) favorable. Such inputs contribute to increasing the output variability.
} 


\section{Figure 2b. Ineffective risk financing instruments}

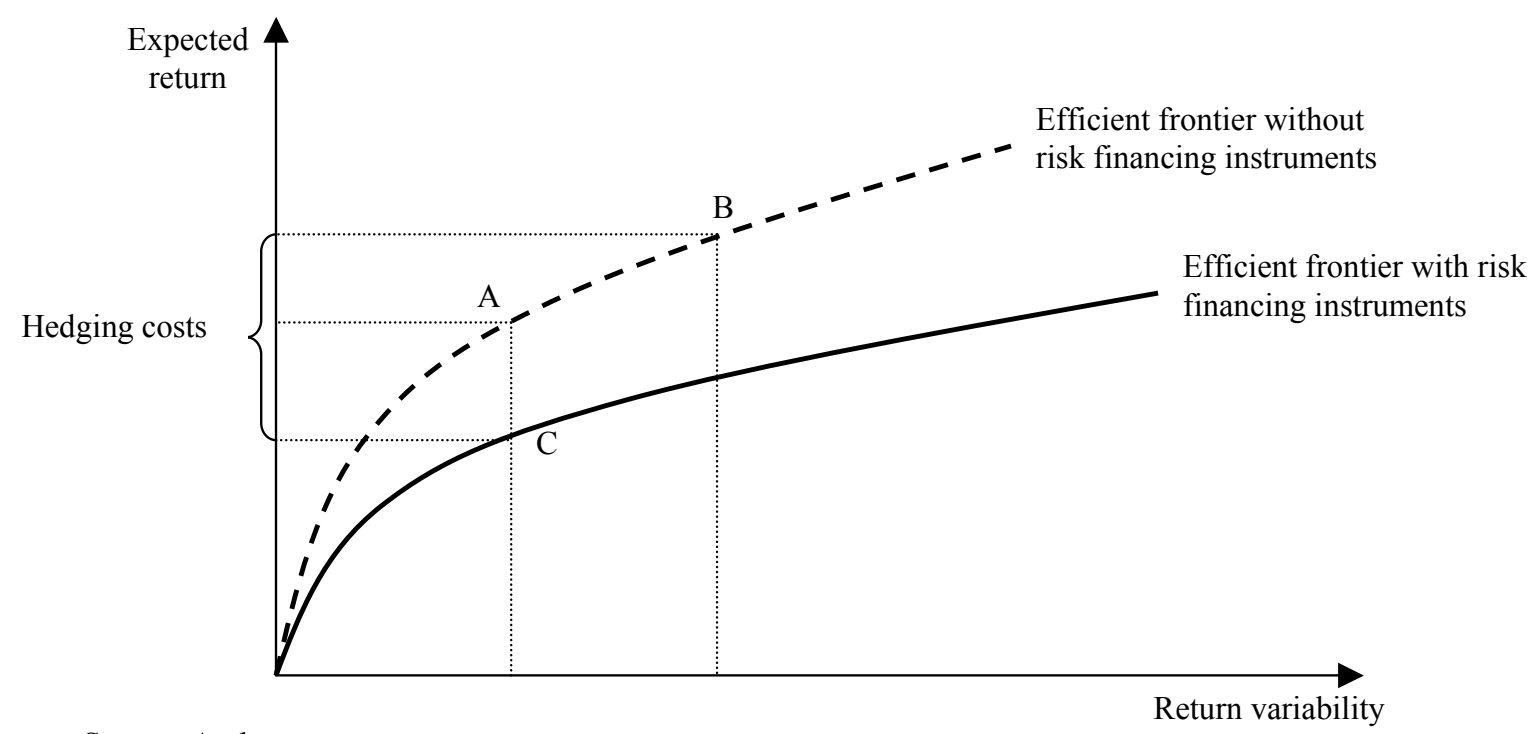

Source: Authors.

Box 3. Risk financing instruments as market-enhancing solutions

Detrended data on cocoa yields from 1961 to 2002 in a South American country are used for the sake of illustration. The hedging costs represent the costs of self-retaining risks and/or the insurance costs, beyond the fair premium.

The catastrophe coverage is assumed to be sold at twice its fair price. The catastrophe insurance costs are thus equal to $0.72 \%$ of the average yield for the production of cocoa and $0.29 \%$ for banana. The non-catastrophe coverage faces insurance costs equal to $50 \%$ of the fair premium (i.e., $50 \%$ loading factor), for the sake of simplicity.

If the crop yield risk is self-retained, the costs of holding the minimum capital requirements (reserve load) represent $15 \%$ of the minimum capital (see Box 2).

The cost of self-retention (reserve load) is higher than the cost of non-catastrophe insurance in the case of the production of cocoa, whatever the average operating profit margin. The costs of hedging against cocoa yield risks are thus equal to the sum of the catastrophe insurance cost and the non-catastrophe insurance costs. On the contrary, self-retaining yield risk is less expensive than transferring the non-catastrophic component of this risk in the case of banana production. The costs of hedging against banana yield risks are thus equal to the sum of the catastrophe insurance cost and the reserve load. 
Table. Cost of internal and external risk-financing solutions (in \% of average yields)

\begin{tabular}{|c|c|c|c|c|c|}
\hline & \multicolumn{5}{|c|}{ Average operating profit margin (in \% of average yields) } \\
\hline & $5 \%$ & $10 \%$ & $15 \%$ & $20 \%$ & $25 \%$ \\
\hline \multicolumn{6}{|l|}{ Cocoa } \\
\hline Cat insurance cost & $0.72 \%$ & $0.72 \%$ & $0.72 \%$ & $0.72 \%$ & $0.72 \%$ \\
\hline Non-cat insurance cost & $5.49 \%$ & $4.47 \%$ & $3.71 \%$ & $3.11 \%$ & $2.57 \%$ \\
\hline Reserve load & $7.08 \%$ & $6.83 \%$ & $6.51 \%$ & $5.36 \%$ & $4.62 \%$ \\
\hline Hedging costs & $6.21 \%$ & $5.19 \%$ & $4.43 \%$ & $3.83 \%$ & $3.29 \%$ \\
\hline \multicolumn{6}{|l|}{ Banana } \\
\hline Cat insurance cost & $0.29 \%$ & $0.29 \%$ & $0.29 \%$ & $0.29 \%$ & $0.29 \%$ \\
\hline Non-cat insurance cost & $3.07 \%$ & $2.01 \%$ & $0.54 \%$ & $0.36 \%$ & $0.28 \%$ \\
\hline Reserve load & $2.25 \%$ & $1.47 \%$ & $0.51 \%$ & $0.31 \%$ & $0.14 \%$ \\
\hline Hedging costs & $2.54 \%$ & $2.76 \%$ & $0.80 \%$ & $0.60 \%$ & $0.43 \%$ \\
\hline
\end{tabular}

Source: Authors.

\subsection{Toward a New Typology of Crop Business Activities}

The crop business viability is related to the ability of the crop business to survive in the long run the exogenous shocks that occasionally generate negative returns. It determines how financially strong a farmer should be to absorb from time to time adverse production shocks without losing the overall long-term profitability of the business.

The above discussion allows us to draw a typology of crop business activities based on farmers viability in the long run, which is illustrated in Figure 3. In Quadrant I, the farmer's asset base is large and the crop business is highly profitable. As a result, this crop business activity is viable and external risk financing solutions may enhance the crop business viability. Quadrant II includes farmers who are productive but asset poor. Market-based solutions could help them to restore the viability of the crop business by providing external capital to finance infrequent adverse production shocks. The farmer would not be able to absorb such shocks without external capital, thus jeopardizing the survivability of the crop business in the long run despite its profitability, which highlights the real value added of market-based risk financing solutions. On the contrary, market-based instruments are not a solution to farmers with a small asset base and a low profitable business, depicted in Quadrant III. These farmers have neither the financial capacity to absorb exogenous shocks because they are asset poor, nor the possibility to transfer part of these production shocks to private markets because their profit margin is too low to cover the hedging costs. Therefore, these crop business activities are not viable in the long run without public support which may or may not be socially desirable. Finally, crop businesses located in Quadrant IV rely on the farmer's large asset base to offset the low profitability of their crop business. However, these activities are not sustainable in the long run as the assets will be eventually depleted because of frequent occurrences of adverse events. 
Figure 3. Typology of crop business activities and market-based solutions

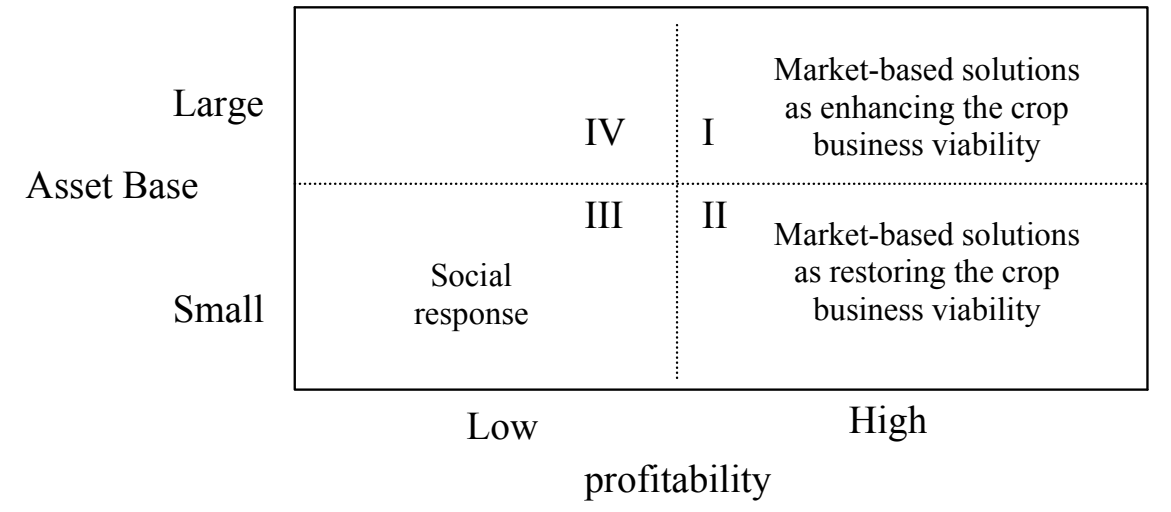

Source: Authors.

According to this typology, there are two groups of productive farmers who could benefit from market-based instruments in financing their exposure to agricultural production shocks without relying on public subsidy programs. Those are (i) the farmers with a large asset base and profitable business (Quadrant I) and (ii) the farmers with low asset base but profitable business (Quadrant II). While the former group can enhance their business viability, the latter can fundamentally improve it.

The test of the crop business viability is synthesized in Figure 4. The operating profit margin is equal to the difference between the realized crop yield and the (non-random) production costs. Operating losses occur when the operating profit margin is negative. The minimum capital required to finance these operating losses is estimated. These losses are financed either by internal funds, which requires a minimum financial reserve, or by external capital like insurance or debt. Both options result in costs such as reserve load and insurance costs. The risk financing costs are then compared with the operating profit margin. Therefore, the crop business activity is considered viable if the average operating profit margin is higher than the hedging costs. For a given crop, the higher the operating profit margin, the lower are the operating losses and the costs of financing these losses through internal or external capital. The test of the crop business viability is illustrated in Box 4. 
Figure 4. Testing the viability of the crop business

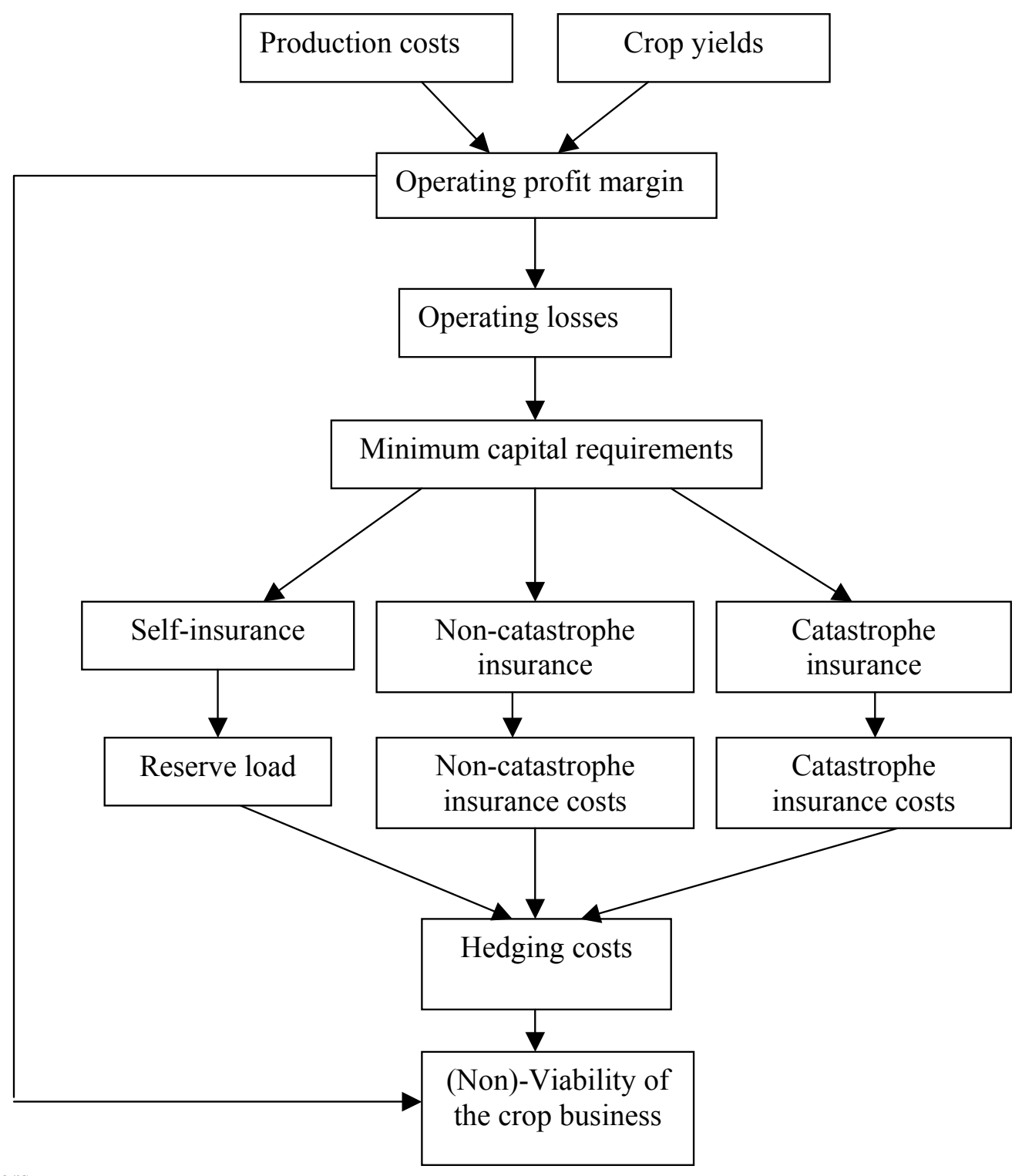

Source: Authors.

\section{Box 4. Crop business viability}

Detrended data on cocoa yields from 1961 to 2002 in a South American country are used for the sake of illustration.

Without access to external capital, cocoa production would be a viable business only for large asset-base farmers given the high level of minimum capital requirements (see Box 2). On the contrary, banana production is less variable and thus the minimum capital requirements are lower, allowing asset poor farmers to be involved in a viable business (see Box 2).

Access to external capital (through insurance) may enhance or restore the viability of the crop business. The cost of hedging against catastrophic losses and hedging/self-retaining non-catastrophic losses is assessed from the 
results presented in Box 3. It is then compared to the operating profit margin for different levels of profit margin generated by different farms. The crop business activity is thus viable if the operating profit margin is higher than the hedging costs.

Crop business viability
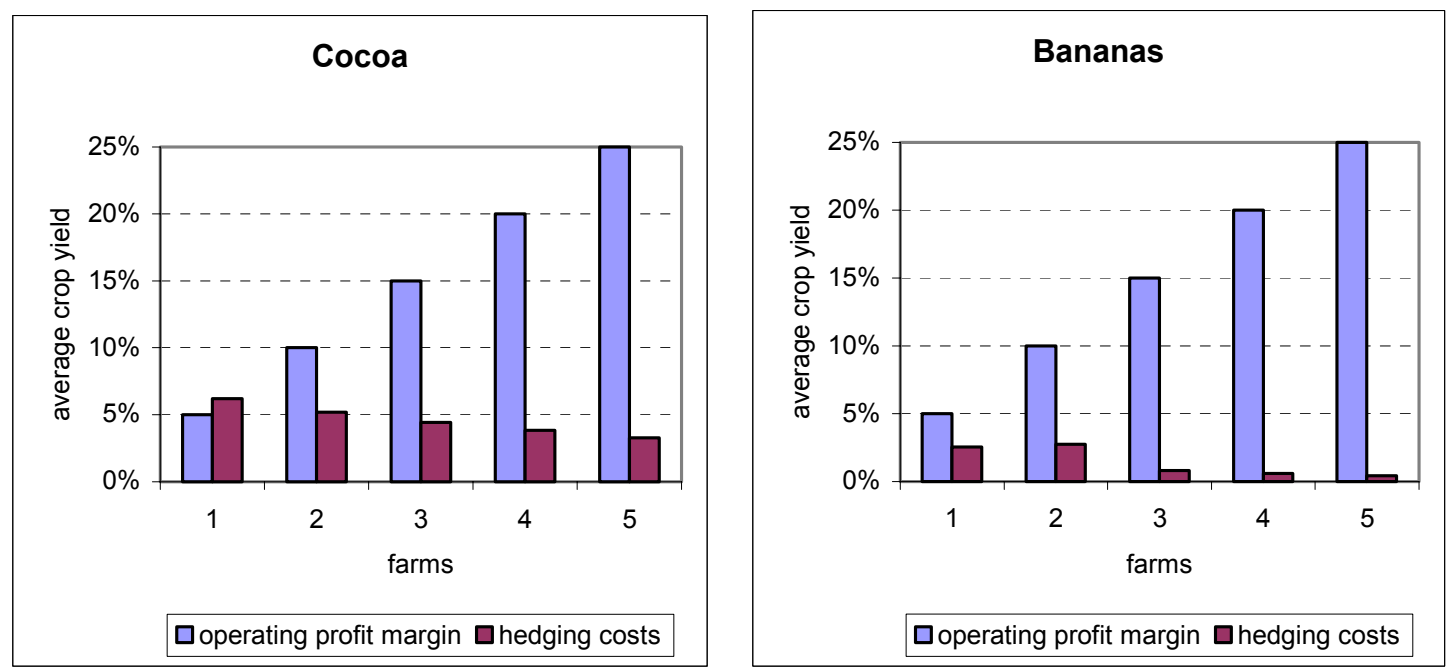

As shown in the figures above, Farm 1 producing cocoa is not viable (its profit margin is lower than its hedging costs), while the other four farms with a higher operating profit margin are viable. All farms producing bananas are viable, even Farm 1, which has the lowest operating profit margin.

Source: Authors.

\section{Insurance and Rural Finance}

\subsection{Combining Risk Financing Instruments}

As we have shown in the previous section, the yield risk characteristics of a specified crop and the farm's production costs allow to characterize the variability of operating losses and thus to estimate the minimum amount of capital required to finance the unexpected exogenous production shocks. In this section, we will demonstrate that this financial capacity does not need to come from one single source such as insurance or savings. In fact, a costefficient risk financing strategy will rely on multiple sources of risk financing ranging from the farmer's internal stock of wealth (savings) to external capital provided by insurers or lenders. We demonstrate that a cost-efficient risk financing strategy should be custom-tailored to the specific needs of farmers and should take into account the characteristics of the underlying risk and the costs of available risk management instruments, with the likely outcome being a combination of insurance, savings, and contingent debt. Figure 5 provides an illustration of how the risk frequency, severity and co-variability characteristics determine the crop's insurability and the choice of risk financing instruments to finance the minimum business capital requirements.

As can be seen from Figure 5, market-based solutions, including insurance, are inefficient to deal with high frequency / high severity risks. For instance, droughts occurring every three years, as it can be observed in some States of India or no less frequent floods in Bangladesh, cannot be financed using market-based insurance solutions. Crops, and consequently the farms involved in their cultivations, which are exposed to risks with such frequency/severity characteristics are unlikely to be viable. When the frequency of the 
production loss is high and severity is low, transaction costs prevent insurance from being an efficient risk-financing instrument. Savings may be the only viable solution. However, this risk financing solution relies on the farmer's ability to build reserves during good years which depends on the profitability of the crop. If the crop is consistently unprofitable, government subsidies through public disaster relief programs may be the only hope in these cases. An alternative solution is to borrow following the occurrence of an adverse event. However, the farmer's borrowing capacity also depends on his ability to repay the loans and thus on the profitability of his business activity. Self-insurance may also be efficient to manage low frequency/low severity events. When infrequent crop yield losses are almost independent, mutual insurance may be a solution. However, the efficiency of this risk pooling strategy depends on the administration costs (delivery costs, agency costs...). Finally, when low frequency / high severity losses are highly correlated among farmers, the only solution is to transfer part of these risks to external investors through reinsurance and/or hedging contracts underwritten by capital market investors to avoid potentially catastrophic losses that can lead to insolvency. However, this market-based solution may be costly and thus it may be affordable for only highly profitable crop business activities.

\section{Figure 5. Risk disaggregation and risk financing instruments}

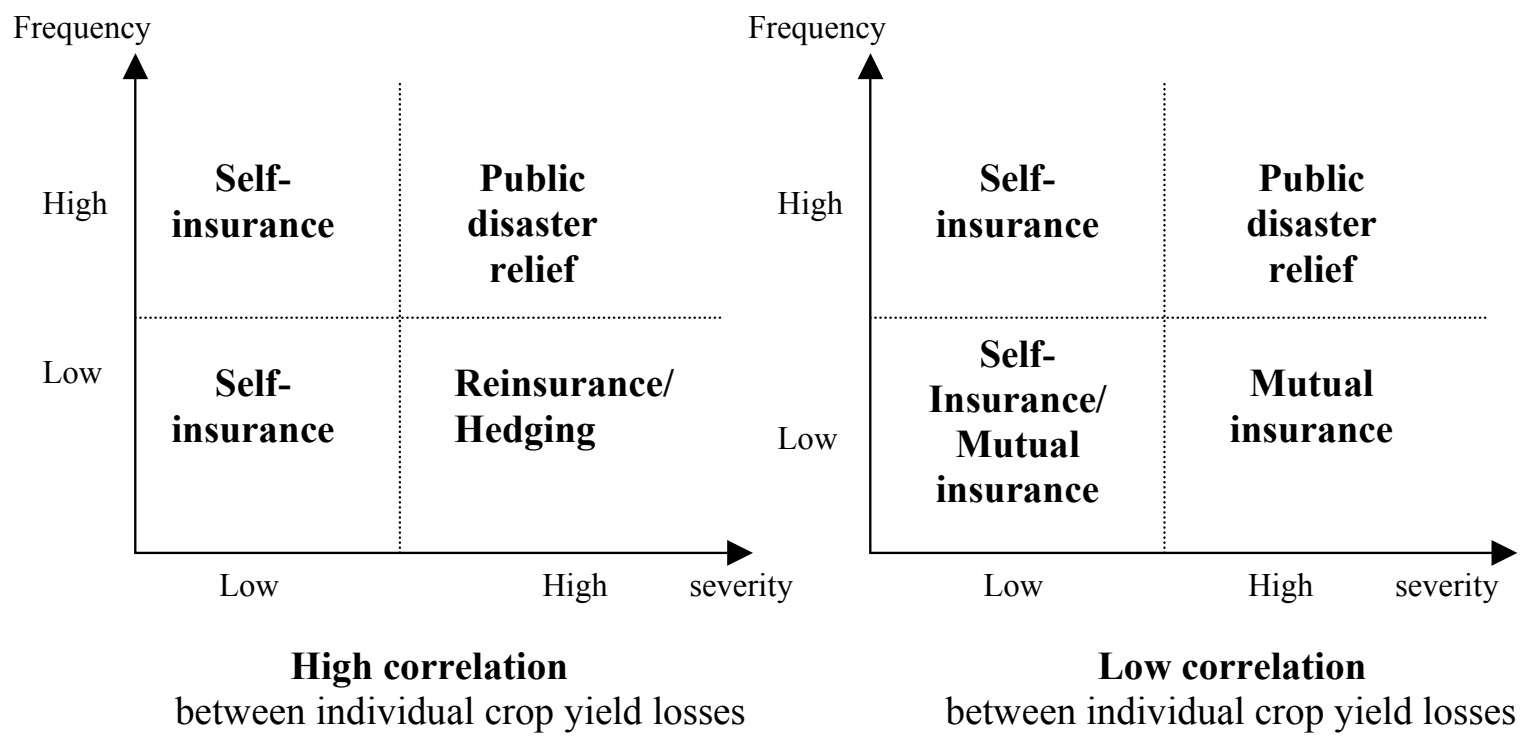

Source: Authors.

\subsection{Combining Insurance and Savings}

The importance of combining insurance and (precautionary) savings as risk management instruments has been recently emphasized in the literature (see, e.g., Siegel 2000, Heitzman, Canagarajah and Siegel 2002). ${ }^{8}$ However, very few studies examine analytically the combined demand for insurance and savings. On the one hand, the insurance

\footnotetext{
${ }^{8}$ Hazell, Pomareda and Valdes (1986) mentioned the potential benefits of such a combination.
} 
economics literature investigates the demand for insurance in a static model where the "time diversification strategy" provided by savings cannot be addressed. On the other hand, the literature on savings is based on a lifecycle consumption model where insurance is considered unavailable for consumers. There is however a few exceptions. Sakurai and Reardon (1997) explore the demand for formal drought insurance and infer the household's willingness to pay for a hypothetical formal drought insurance. Their results generally support the hypothesis that "those who are wealthier and/or more self-insured demand less formal drought insurance" (p.1206). Using a fairly simple simulation model, Gollier (2003) shows that the ability for consumers to self-insure by accumulating buffer stock wealth, i.e., precautionary savings, induces them to significantly reduce their demand for insurance. In other words, the added value of insurance may be small when self-insurance can finance the loss. As a consequence, only liquidity constrained households would purchase a high level of coverage, while wealthier people would mostly rely on their ability to engage in inter-temporal diversification strategies. These main findings of the model can be recast in a two-period model (see Box 5). The household's ability to build risk-free savings induces it to increase its insurance coverage. The optimal insurance coverage and the optimal amount of savings are driven by the cost of insurance, the rate of return on savings, the household's initial wealth and the risk characteristics.

\section{Box 5: Insurance and savings}

Insurance and savings as substitutes or complements are investigated in a simple two period model. The agent is endowed with an initial wealth at the beginning of each period. In the second period, he faces a risk of loss. The loss is characterized by its severity $l$ (expressed in percentage of the initial wealth) and its frequency $p$. The agent can manage this risk by purchasing insurance in the second period and/or by building savings during the first period. He maximizes the discounted expected utility of his final wealth, with his utility function exhibiting constant relative risk aversion.

As a first approximation, the optimal amount of savings $s^{*}$ and the optimal level of coverage $D^{*}$, defined as a percentage of the loss, are solutions of the following system of two equations

$$
\begin{aligned}
& s^{*}=\frac{1}{\gamma\left[1+\beta(1+r)^{2}\right]}\left[\beta(1+r)-1+\beta(1+r) \gamma\left(p\left(l-D^{*}\right)+0.5 p(1-p)\left(l-D^{*}\right)^{2}(\gamma+1)\right)\right] \\
& D^{*}=\frac{(1-k)(1-(1+\lambda) p l)}{[1-(1-k)(1+\lambda) p] l}\left(1+\beta(1+r) s^{*}\right) \text { with } k=\left[\frac{(1+\lambda)(1-p)}{1-(1+\lambda) p}\right]^{-1 / \gamma},
\end{aligned}
$$

where $\beta$ is the rate of time preference, $r$ is the interest rate, $\gamma$ is the agent's degree of relative risk aversion and $\lambda$ is the loading factor of the insurance policy.

Source: Authors, adapted from Gollier (2001).

The optimal risk-financing strategy using insurance and savings is illustrated in Figure 6 using the approximate analytical solutions provided in Box 4. They illustrate how the optimal strategy would depend on (i) the crop yield risk characteristics summarized here by the return period and the average loss per event and (ii) the farmer's financial profile and particularly by his ability to finance unexpected adverse production shocks.

The farm faces a loss characterized by the return period (i.e., $1 / p$ where $p$ is the annual probability of occurrence of the loss event) and the average loss per event $l$ expressed in percentage of the farmer's wealth. The annual average loss is assumed to be one percent of 
the farmer's wealth, that is $p l=1 \%$. A one in 90 year event corresponds to a low frequency $(p=1.11 \%)$ and high severity $(l=90 \%)$ event, while a one in two year event has a high frequency $(p=50 \%)$ and a low severity $(l=2 \%)$. Because the expected loss is constant and equal to one percent of the wealth, $p l=1 \%$, the higher the return period, the higher the average loss per event $l$. Savings refer to the transfer of past earnings (e.g., retained earnings) accumulated over time while self-retention refers to the use of current earnings. The riskfinancing structure is defined as a percentage of the average loss per event. An external source of capital is available through insurance.

Figure 6a depicts the optimal risk financing strategy for a farmer with a large asset base. The optimal strategy is based on the tradeoffs between the marginal costs of riskfinancing instruments. Not surprisingly, insurance is the main risk-financing instrument to address catastrophic events. Insurance covers more than $80 \%$ of the average loss per event for the events with a return period higher than 40 years. The insurance coverage declines as the event becomes more frequent and less severe. In this illustration, only one percent of the loss is insured in case of a one in two years event. On the contrary, self-financing (savings and self-retention) increases as the loss event becomes more frequent. Self-financing covers less than $15 \%$ of the one in 90 year loss and $99 \%$ of the one in two years event. The fraction of the self-financed loss goes from $3 \%$ for the one in 90 year event to $60 \%$ for the one in two years event.

The optimal risk financing structure is reexamined when the farmer's asset base is small. This means that his ability to raise internal funds to finance adverse production shocks is limited. For the sake of illustration, we assume that internal capital provided by selfinsurance (savings and self-retention) can only cover losses lower than or equal to $3 \%$ of the farmer's wealth. This creates a financial constraint which enhances the role of insurance as a provider of external capital. The optimal risk financing structure of the asset poor farmer is depicted in Figure 6b. As expected, this financial constraint forces the farmer to transfer a larger fraction of the risk to an insurance company, except for the one in two years event under which the average loss per event $l$ is $2 \%$, which is lower than the farmer's internal financial capacity. Insurance covers more than $90 \%$ of the loss caused by one in twenty year events or less frequent events and $80 \%$ of losses caused by a one in ten year event, compared to less than $60 \%$ when the asset base was large.

However, one missing piece in the above-mentioned model is that the rate of return on savings is assumed to be risk free. This assumption may not hold in developing countries. If savings are invested in risky assets, then the strategy of capital accumulation becomes more expensive compared to insurance and, consequently, the demand for insurance becomes higher. In other words, insurance becomes a more valuable service even for asset rich farmers as long as capital accumulation is limited and/or subject to random shocks. 
Figure 6a. Optimal risk-financing strategy for a farmer with large asset base

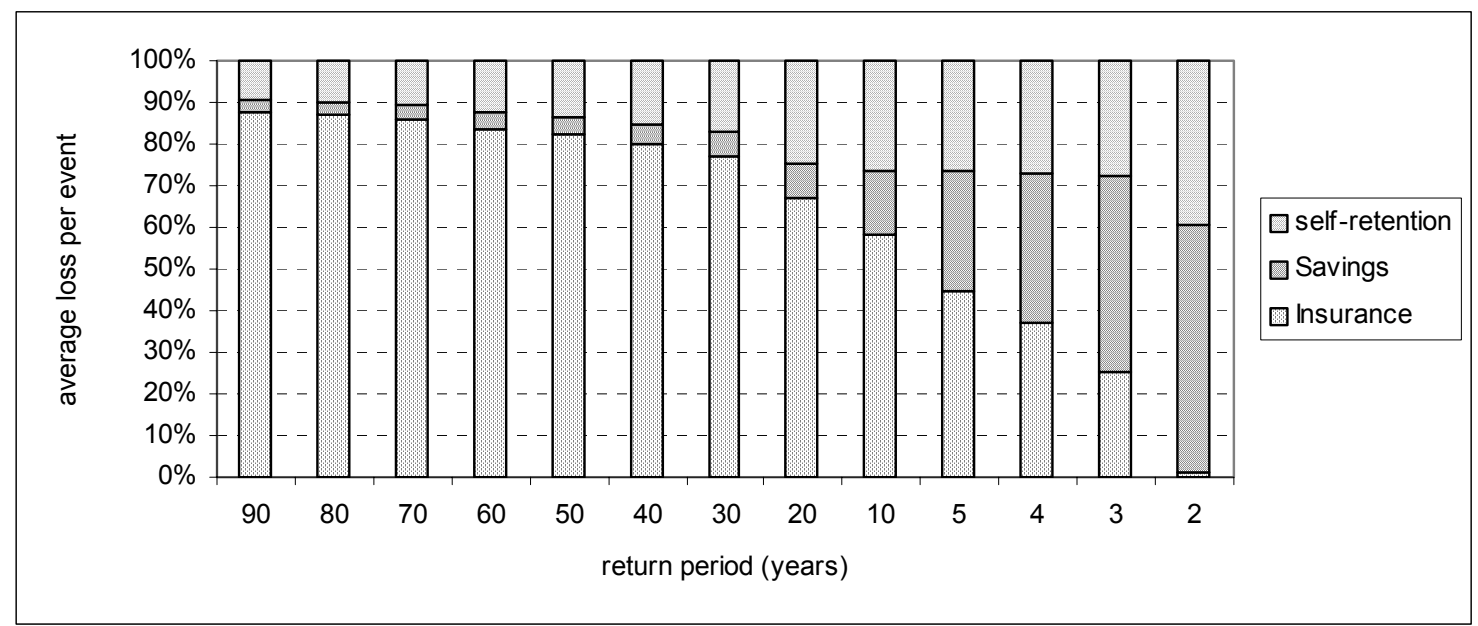

Assumptions: $\beta=0.98, r=5 \%, \gamma=2, \lambda=0.3, p l=1 \%$.

Source: Authors.

Figure 6b. Optimal risk-financing strategy for a farmer with small asset base

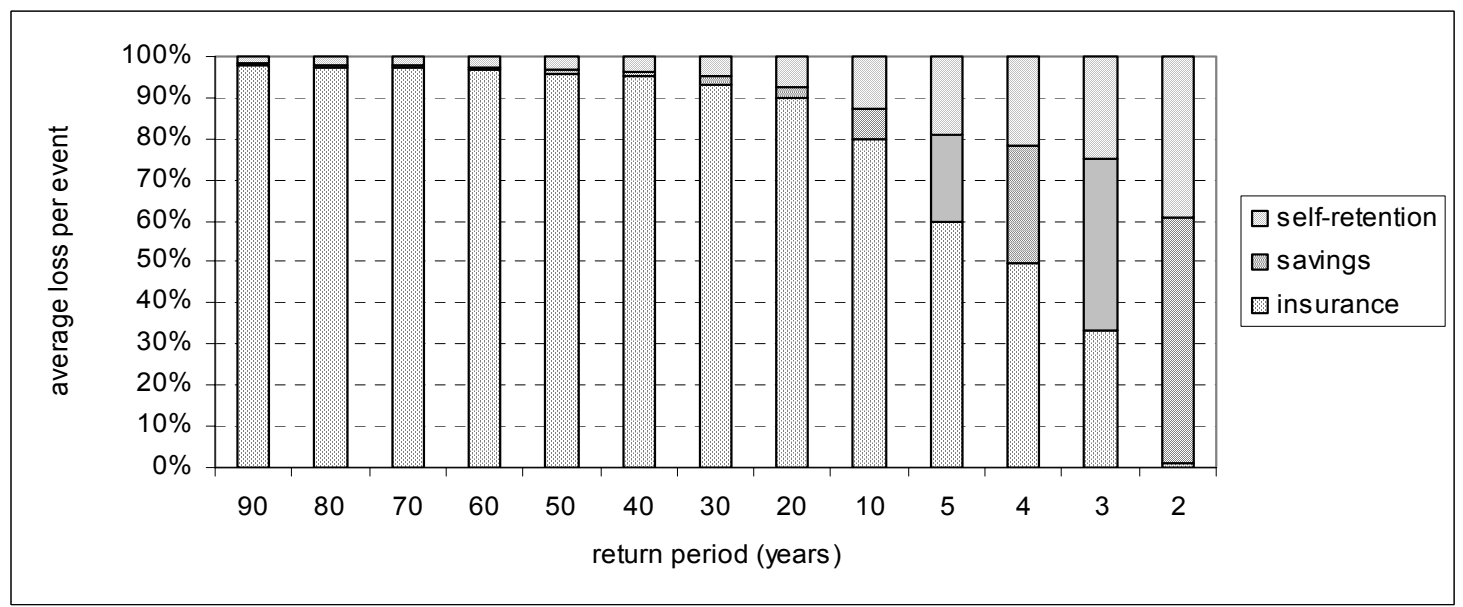

Assumptions: $\beta=0.98, r=5 \%, \gamma=2, \lambda=0.3, p l=1 \%$, internal financial capacity: $3 \%$.

Source: Authors.

\subsection{Combining Insurance and Contingent Debt}

Contingent borrowing is a post-loss financing instrument offered by financial markets as an alternative risk-financing solution. It is arranged on an ex ante basis. The agent first pays a loan contingent fee and, in the event of a loss, it receives the full principal of the prearranged loan that will be repaid over time. At the farmer's level, such an arrangement can be viewed as a pre-agreed emergency loan. Gurenko and Mahul (2003) develop an analytical model to examine the optimal risk-sharing arrangements using insurance, self-retention and contingent debt for different layers of risk. They show how the risk financing structure as well as the risk sharing rule within each layer of risk are driven by the cost of internal capital, the cost of insurance, the cost of external capital and the risk characteristics. Under some 
plausible assumptions, the optimal risk financing structure takes the form as depicted in Figure 7. Full self-retention is optimal for small losses in Layer I. Partial self-retention and contingent debt are optimal in Layer II. In Layer III, insurance, contingent debt and selfretention are jointly used. Finally, because of the borrowing constraint, the loss in the upper layer IV is partly covered using insurance and the remaining loss is self-retained.

Figure 7. Optimal risk management strategy using insurance, contingent debt and selfretention, non-proportional insurance premium.

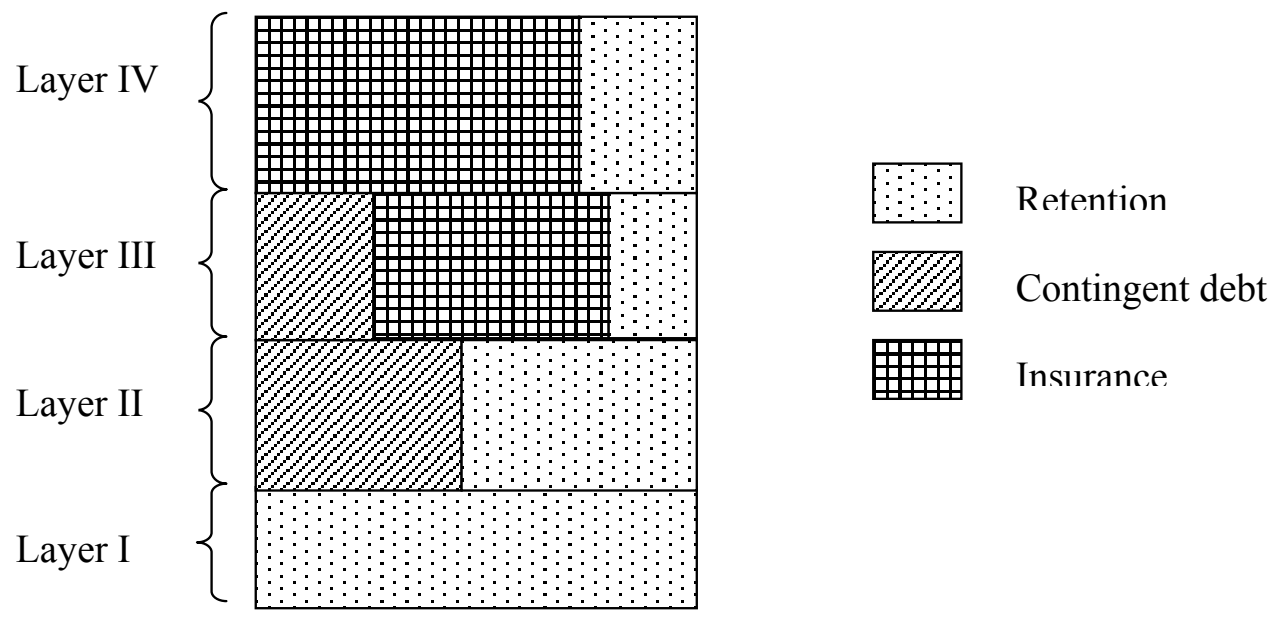

Source: Gurenko and Mahul (2003).

The insurance cost due to the variability of the loss is a key parameter in the design of the optimal risk-financing strategy. As this variability cost increases, (i) the level of self-retention increases in layers III and IV and remains constant in Layer I, (ii) the level of contingent debt increases in Layer III and is unchanged in Layer IV, and (iii) the level of insurance decreases in layers III and IV but always remains larger in Layer IV (Gurenko and Mahul 2003).

\section{Conclusion}

This paper examines how market-based risk financing instruments could enable productive but asset-poor farmers exposed to production shocks to engage in riskier but higher return agricultural activities and thus escape poverty. It designs a conceptual framework to address the financing of agricultural production shocks using market-based risk financing instruments. Its contribution to the debate on agricultural risk management is twofold:

- It tests the business viability of a specified crop by assessing the minimum business capital requirements needed to ensure the continuity of the crop business after the occurrence of an adverse production shock and the farmer's ability to meet it; and

- It offers an innovative conceptual approach for the design of an optimal risk management program to finance the minimum capital requirements using a combination of risk financing instruments, such as insurance, savings, and contingent debt. 
The illustrative examples proposed throughout the paper highlight the relevance and applicability of the proposed conceptual approach to the real challenges faced by agricultural risk management practitioners.

The proposed market-based approach would also allow government policy makers to design cost-effective fiscal interventions in restoring the viability of productive but asset-poor farms. The developed conceptual framework can help with the targeting of subsidies in agriculture by (i) identifying the types of farmers who can benefit from subsidies most and (ii) assessing the amount of subsidies needed to restore the viability of their agricultural business.

While the focus of the paper is on exogenous production shocks, the conceptual framework can easily encompass exogenous price shocks as well, which ultimately can lead to the design of comprehensive risk financing solutions to address all exogenous agricultural income shocks. These natural extensions of our market-based approach are left to further research.

The existing agricultural insurance programs are heavily subsidized by the governments in almost all countries around the world, with most of the subsidies captured by large farmers. The lack of clarity regarding the objectives of these programs contributes to undermining their effectiveness. The proposed financial framework can thus provide useful business guidelines in the design and implementation of agricultural insurance programs, helping to enable productive but asset-poor farmers to succeed in their business. 


\section{References}

Anderson, J. (2001). Risk management in rural development: a review. The World Bank, Rural Strategy Background Paper 7.

Barry, P. (2002). Finance and risk bearing in agriculture, in R. Just and R. Pope (Eds.), A Comprehensive Assessment of the Role of Risk in U.S. Agriculture, Kluwer Academic Publishers.

Binswanger, H. and J. McIntire (1987). Behavioral and material determinants of production relations in land-abundant tropical agriculture, Economic and Development Cultural Change 36(1), 73-99.

Dercon, S. (2002). Income risk, coping strategies and safety nets, Discussion paper 2002/22, World Institute for Development Economic Research.

Doherty N. (1985). Corporate Risk Management: A Financial Exposition, McGraw-Hill Book Company, New York.

Doherty, N. (2002). The cost of risk and the cost of capital in capital-budgeting and risk transfer decisions, in M. Lane (Ed.), Alternative Risk Strategies, Risk Books.

FAO. Food and Agriculture Organization (1991). Strategies for Crop Insurance, FAO report.

FAO. Food and Agriculture Organization (1998). Agricultural Finance Revisited: why?, FAO report.

Hueth, D. and W. Fortan (1994). Economics of Agricultural Crop Insurance: Theory and Evidence, Kluwer Academic Publishers.

Gollier, C. (2003). To insure or not to insure?: an insurance puzzle, The Geneva Papers on Risk and Insurance 28, 5-24.

Gurenko, E. and O. Mahul (2003). Combining insurance, contingent debt and self-retention an optimal corporate risk financing strategy. World Bank Working Paper 3167.

Harrington, S. and G. Niehaus (1999). Risk Management and Insurance, McGraw-Hill Book Company, New York.

Hazell, P., C. Pomareda and A. Valdes (1986). Crop Insurance for Agricultural Development, The Johns Hopkins University Press, Baltimore.

Holzmann R. and S. Jorgensen (2000). Social risk management: a new conceptual framework for social protection and beyond, The World Bank, Social Protection Discussion Paper 0006.

Miranda, M.J, and J.W. Glauber (1997). Systemic risk, reinsurance, and the failure of crop insurance markets, American Journal of Agricultural Economics 79(2), 206-15.

Sekurai, T. and T. Reardon (1997). Potential demand for drought insurance in Burkina Faso and its determinants, American Journal of Agricultural Economics 79(4), 1193-1207.

Siegel, P. (2000). Towards an integrated approach to manage risk in rural areas, Paper presented at the $26^{\text {th }}$ International conference of agricultural economists, August 13-18, 2003, Berlin, Germany.

Siegel, P., J. Alwang, and S. Canagarajah (2001). Viewing microinsurance as a social risk management instrument, The World bank, Social Protection Discussion Paper 0116. 